\title{
The fishing and illegal trade of the angelshark: DNA barcoding against misleading identifications
}

\section{Ingrid Vasconcellos Bunholi ${ }^{\mathrm{a}}$, Bruno Lopes da Silva Ferrette ${ }^{\mathrm{a}, \mathrm{b}, *}$, Juliana Beltramin De Biasi ${ }^{\mathrm{a}, \mathrm{b}}$, Carolina de Oliveira Magalhães $^{\mathrm{a}, \mathrm{b}}$, Matheus Marcos Rotundo ${ }^{\mathrm{c}}$, Claudio Oliveira ${ }^{\mathrm{b}}$, Fausto Foresti ${ }^{\mathrm{b}}$, Fernando Fernandes Mendonça ${ }^{a}$}

${ }^{a}$ Laboratório de Genética Pesqueira e Conservação (GenPesC), Instituto do Mar (IMar), Universidade Federal de São Paulo (UNIFESP), Santos, SP, 11070-102, Brazil

${ }^{\mathrm{b}}$ Laboratório de Biologia e Genética de Peixes (LBGP), Instituto de Biociências de Botucatu (IBB), Universidade Estadual Paulista (UNESP), Botucatu, SP, 18618-689, Brazil

${ }^{\mathrm{c}}$ Acervo Zoológico da Universidade Santa Cecília (AZUSC), Universidade Santa Cecília (Unisanta), Santos, SP, 11045-907, Brazil

\section{A R T I C L E I N F O}

Handled by J Viñas

Keywords:

Conservation

Endangered species

Fishing monitoring

Forensic genetics

Mislabeling identification

\begin{abstract}
A B S T R A C T
Morphological identification in the field can be extremely difficult considering fragmentation of species for trade or high similarity between congeneric species. In this context, the shark group belonging to the genus Squatina is composed of three species distributed in the southern part of the western Atlantic. These three species are classified in the IUCN Red List as endangered, and they are currently protected under Brazilian law, which prohibits fishing and trade. Molecular genetic tools are now used for practical taxonomic identification, particularly in cases where morphological observation is prevented, e.g., during fish processing. Consequently, DNA barcoding was used in the present study to track potential crimes against the landing and trade of endangered species along the São Paulo coastline, in particular Squatina guggenheim $(\mathrm{n}=75)$ and $S$. occulta $(\mathrm{n}=5)$, as well as the Brazilian guitarfish Pseudobatos horkelii $(\mathrm{n}=5)$. DNA barcoding revealed the continuous fishing and trafficking of these protected species, thus giving clear evidence that the current conservation models and methods of monitoring are not working.
\end{abstract}

\section{Introduction}

The Elasmobranchii subclass of Chondrichthyes currently consists of 509 shark species and 630 rays (Weigmann, 2016). However, this biodiversity should be greater owing to the continuous description of new species in recent years (Borsa, 2016). Out of this total, more than $90 \%$ is listed on the IUCN Red List with about $16.5 \%$ in the threatened categories and at least 40\% listed as "Data Deficient" (IUCN, 2017). Such statistics call for the immediate collection of biological data toward formulating and implementing novel plans for the conservation of these species.

Several characteristics make this group especially susceptible to overexploitation, such as longevity, late sexual maturation, low fecundity and long gestation periods (Stevens et al., 2000; Dulvy et al., 2008; Field et al., 2009). Consequently, many Elasmobranch species are impacted by artisanal fisheries, as well as recreational and industrial fishing for meat, fins, liver oil, or cartilage (Vannuccini, 1999). Early on, the lower commercial values of these species tended to limit direct exploitation (Walker, 1999; Molina and Cooke, 2012). Nowadays, however, estimates indicate that about 100 million sharks are caught annually, even when excluding illegal, unreported and unregulated catches (Liu et al., 2013).

Even with growing awareness of the vulnerability of most species of sharks and rays to exploitation (Castro, 1987; Camhi, 1998), attempts to manage species of this group have largely failed, essentially by the lack of basic information on catches, landings, and commercial sales. The correct management of any species, including Elasmobranch, is based on precise identification (Oliver et al., 2015; Davidson et al., 2016). In this case, however, morphological identification is made very difficult by the common fishing practice of cutting off the head, fins and tail, which are deposited at sea, to increase the space needed for storage and to preserve the meat longer (De Franco et al., 2012).

Among exploited sharks, angelsharks comprise the second most threatened Elasmobranch family globally, and they stand out in many regions of the world (Dulvy et al., 2014; Meyers et al., 2017). The angelshark genus Squatina (Squatinidae) comprises 22 extant,

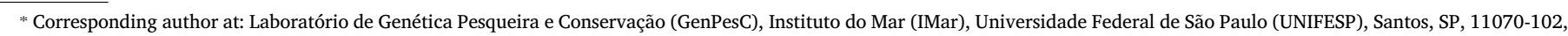
Brazil.

E-mail address: brunoferrette@gmail.com (B.L.S. Ferrette). 
morphologically homogeneous, benthic species (Vooren and Da Silva, 1992; Compagno, 2005; Castro-Aguirre et al., 2006; Last and White, 2008), which inhabit continental shelves and upper slopes down to $500 \mathrm{~m}$ (Compagno, 2005). They are moderately sized (total length about 1-2 m) and globally distributed in temperate to tropical seas (Compagno, 2005; Last and White, 2008). While some species occur over a wide geographic range, most are restricted to a smaller area (Compagno, 2005). Among the species distributed in the coastal waters of southeastern Brazil and Patagonian central Argentina (Cousseau and Figueroa, 2001; Vooren and Klippel, 2005), the spiny angelshark Squatina guggenheim, the Argentine angelshark $S$. argentina, the Hidden angelshark $S$. occulta and the Atlantic angelshark $S$. dumeril are frequently landed and marketed, despite conservation laws controlling local fisheries. The morphological identification of such phylogenetically closely related species is particularly difficult, and Vaz and de Carvalho (2013) have only recently reviewed the taxonomy of the genus and validated three of these species, especially samples with morphological traits related to angelsharks.

Given these results, the development of molecular tools applied to species identification has gained in importance, especially for the quantification of exploited natural populations, evaluation and inspection of the trade of species under government protection, and the certification of processed products, adding value to their commercialization (Ogden, 2008; Migone and Howlett, 2012; Maralit et al., 2013; Helyar et al., 2014). Studies using genetic identification of fishery products are appearing in the literature with more frequency, and some of them have been directed to the shark group (e.g., Clarke et al., 2006; Sebastian et al., 2008; De Franco et al., 2012; Maduna et al., 2017).

In view of the capture and commercialization of Elasmobranch species worldwide, even legally protected species, the usual method of fish processing that prevents morphological identification, and the natural difficulties encountered when distinguishing a large number of species, the present study aimed to use DNA barcoding to track potential crimes against the landing and trade of endangered species along the São Paulo coastline.

\section{Material and methods}

\subsection{Sampling}

The samples were obtained between 2015 and 2016 from industrial fishing boats that use bottom trawls and from regional fish distribution markets in the coastal regions of São Paulo, Brazil (Fig. 1). Muscle fragments were collected from 85 carcasses declared by fishermen and traders only as cação (shark) in the cities of Ubatuba (13), Santos (15), Praia Grande (1), Peruíbe (1) and Cananéia (55). Researchers were able to identify morphological traits and relate them to angelsharks. Collected material was preserved in $95 \%$ ethanol and stored at $-20{ }^{\circ} \mathrm{C}$ at the Laboratório de Genética Pesqueira e Conservação (GenPesC) at the Universidade Federal de São Paulo (UNIFESP), Campus Baixada Santista.

\subsection{DNA extraction, amplification and sequencing}

Genomic DNA extraction was done with the NucleoSpin ${ }^{\oplus}$ Tissue kit (Macherey-Nagel), following the manufacturer's instructions. Amplification of the mitochondrial cytochrome oxidase $c$ subunit I gene (COI) was performed using the enzyme Platinum ${ }^{\circledR}$ Taq DNA Polymerase (Thermo Fisher Scientific) with the following primers: Forward FishF1: 5'-TCA ACC AAC CAC AAA GAC ATT GGC AC-3' and Reverse FishR1: 5'-TAG ACT TCT GGG TGG CCA AAG AAT CA-3' (Ward et al., 2005). After amplification, PCR products were subjected to enzymatic purification using the ExoSAP-IT ${ }^{\mathrm{TM}}$ PCR Product Cleanup Reagent (Thermo Fisher Scientific). Sequencing followed the BigDye Terminator v3.1 Cycle Sequencing kit protocol (Thermo Fisher Scientific), and the sequences were generated by the ABI PRISM ${ }^{\circ} 3100$ Genetic Analyzer (Thermo Fisher Scientific) automatic sequencing platform.

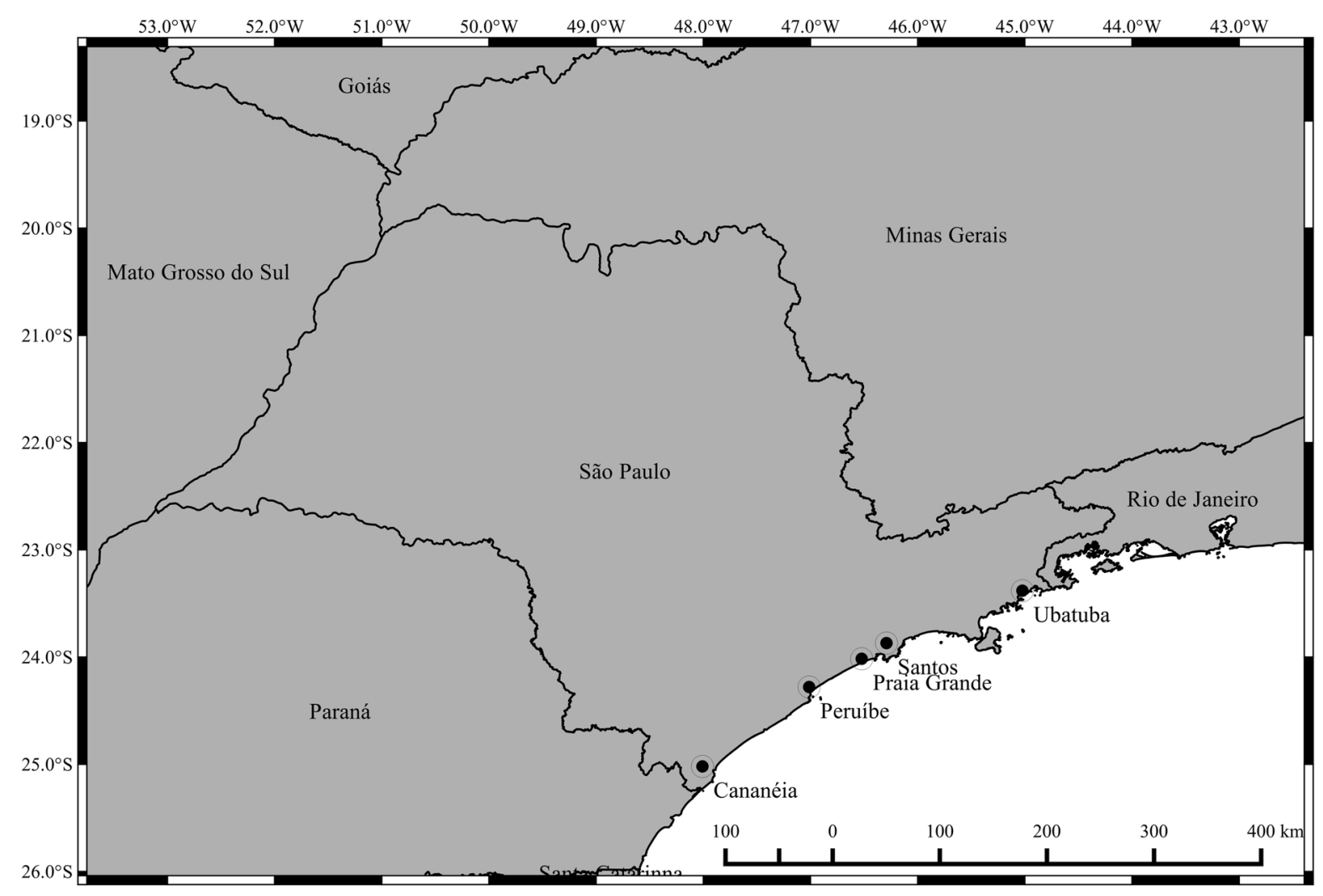

Fig. 1. Sampling by geographic location in the State of São Paulo, Brazil. Black dots represent the algelsharks sampling localities. 
Table 1

Angel shark species sampled along the São Paulo coast, Brazil. $n$, number of samples collected per region.

\begin{tabular}{lllll}
\hline São Paulo region & $n$ & Squatina guggenheim & S. occulta & Pseudobatos horkelii \\
\hline Ubatuba & 13 & 9 & 4 & - \\
Santos & 15 & 9 & 1 & 5 \\
Praia Grande & 1 & 1 & - & - \\
Peruíbe & 1 & 1 & - & - \\
Cananeia & 55 & 55 & - & - \\
Total & 85 & 75 & 5 & 5 \\
\hline
\end{tabular}

\subsection{Analysis and species identification}

The analyses were performed in two steps. First, we compared the similarity of sequences generated individually with the species sequences morphologically identified and available in the Barcode of Life Online Database (BOLD) (http://www.boldsystems.org/) (Ratnasingham and Hebert, 2007) and the Basic Local Alignment Tool (BLAST) (https://blast.ncbi.nlm.nih.gov/Blast.cgi) from GenBank (Benson et al., 2017). Only sequences with more than $99 \%$ similarity to the sequences deposited in these databases were considered.

Next, the evolutionary history was inferred using the neighborjoining method (Saitou and Nei, 1987) with1000 bootstrap replications shown next to the branches (Felsenstein, 1985). The evolutionary distances were computed using the Kimura 2-parameter (K2P) method (Kimura, 1980) as a model of DNA sequencing evolution to distinguish species found in this study from those in global databases and to give greater support to the identifications. To construct the phylogenetic tree, the generated sequences and sequences extracted from the BOLD and GenBank databases were aligned through the MUltiple Sequence Comparison by Log-Expectation (MUSCLE) algorithm (Edgar, 2004), using Molecular Evolutionary Genetics Analysis (MEGA7) software (Kumar et al., 2016) to conduct sequence alignment and infer phylogenetic trees. As an external group, sequences deposited in the BOLD database for the Goblin shark (Mitsukurina owstoni) were selected, and another two species, the Atlantic angelshark Squatina dumeril and the Southern guitarfish Pseudobatos percellens, were utilized to reinforce the molecular identification between closely related species.

\section{Results}

The species of the 85 carcasses were identified and denominated as cação (shark) by fishermen and merchants of the São Paulo coast. In the genetic analysis, high similarity (99.73\% to $100 \%)$ was obtained between the DNA sequences generated and the specific standard sequences available in the databases. In all samples, three species of Elasmobranchs were identified (Table 1), most of which belonged to the Spiny angelshark Squatina guggenheim $(\mathrm{n}=75,88.23 \%)$, the Hidden angelshark Squatina occulta ( $\mathrm{n}=5,5.88 \%)$, and the Brazilian guitarfish Pseudobatos horkelii (Last et al., 2016) ( $\mathrm{n}=5,5.88 \%$ ), recently renamed from the genus Rhinobatos. The COI DNA sequences were submitted to the GenBank database under the accession numbers MF795326 to MF795410. The analysis involved 30 sequences. Codon positions included were $1 s t+2 n d+3 r d+$ Noncoding. All gaps and missing data were eliminated. The final dataset consisted of a total of 651 base pairs in the final dataset (Fig. 2).

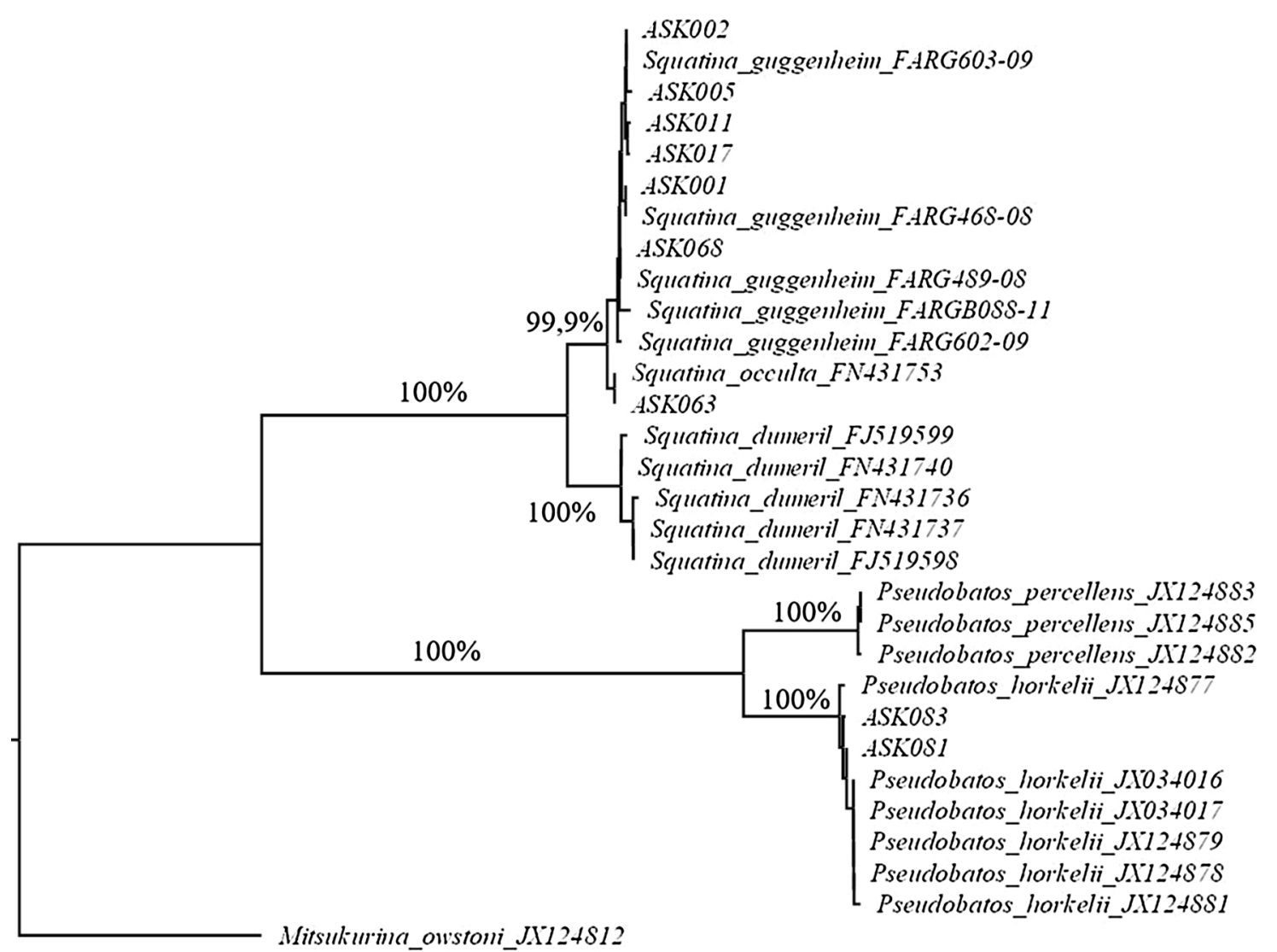

Mitsukurina_owstoni_JX12 $4 S 12$

$A S K 00$

Squatina_guggenheim_F.ARG603-09

ASK005

ASK017

SKOOI

Squatina_guggenheim FARG46S-0S

ASK06S

Squatina_guggenheim_FARG4S9-0S

Squatina guggenheim F.ARG602-09

Squatina_occulta_FN+31753

Seucating

Squatina dumeril_FJ519.59S

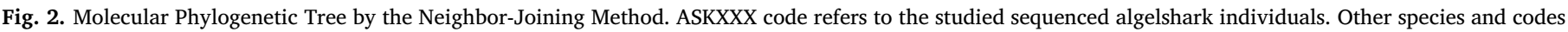
refer to GenBank and BOLD sequences. The percentage in the branches refer to the bootstrap confidence levels for phylogenetic trees. 


\section{Discussion}

This study revealed the capture and commercialization of three species of Elasmobranchs, the angelsharks Squatina guggenheim and $S$. occulta and the Brazilian guitarfish Pseudobatos horkelii, all registered on the Brazilian List of Endangered Species - Fish and Aquatic Invertebrate. According to Normative Instruction No. 005 of May 21, 2004, revalidated by Ministerial Order № 445 of December 17, 2014, the capture, transportation, storage, handling, processing, and trade of these species are completely prohibited in Brazil.

In addition to the threatened species status imposed by the Brazilian government, S. guggenheim is listed as "Endangered" (EN) on the IUCN Red List, underscoring the significant fishing pressure on this species throughout its area of incidence (Chiaramonte and Vooren, 2007). Angelsharks are heavily fished in southern Brazil, and significant declines have been documented. An angelshark bottom gillnet fishery commenced around 1990, and at present, large numbers of angelsharks are caught this way (Villwock de Miranda and Vooren, 2003). According to research trawl surveys of the outer shelf in the years 1986/ 87 and 2001/02, the abundance of the Spiny angelshark in southern Brazil had decreased by $85 \%$, which was attributed to recruitment overfishing. Furthermore, pupping and nursery areas in Brazil occur in shallow inshore waters at depths of $<30 \mathrm{~m}$. Intensive fishing by gillnet and trawl in these nursery areas results in additional pressure on gravid females and juveniles of the species (Silva 1996, Vooren and Klippel, 2005).

Squatina occulta is still listed on the IUCN Red List as "Not Evaluated" (NE). However, its taxonomic status remains controversial (Solé-Cava et al., 1983; Solé-Cava and Levy, 1987; Vooren and da Silva, 1992; Soto, 2001). Based on the IUCN Red List, the species appears as a synonym of $S$. punctata, which is classified as "Endangered" (Musick and Kyne, 2007), even though genetic analysis has validated the species (Furtado-Neto and Carr, 2002; Stelbrink et al., 2010; Falcão et al., 2014). In our phylogenetic tree, $S$. occulta appears as a distinct species and sister group of $S$. guggenheim in concordance with Stelbrink et al. (2010).

Although erroneously related to angelshark carcasses, sampling of the species $P$. horkelii signals the extent of environmental crimes that have been continuously practiced in this region of Brazil. This species is endemic to the southwestern Atlantic. Its distribution center in southern Brazil is subject to trawling in coastal waters, even though it relies on these regions for breeding and nursery areas. Given the reported decline, with the abundance of this species having decreased by $>80 \%$ since 1986 , and continued fishing pressure in its area of occurrence, the species is rated as "Critically Endangered" (CR) by the IUCN Red List. As pointed out by estimates, without proper protection, this ray could be extinct in about ten years (Lessa and Vooren, 2016). Although protected in Brazil, its capture seems to be continuing, despite laws against this practice and the denunciations coming from researchers and environmentalists. In an evaluation performed by De Franco et al. (2012) using genetic markers to identify species of guitarfish captured and traded in southeastern Brazil, the exploitation of $P$. horkelii was verified as comprising about $56 \%$ of rays exploited in Brazil. In the present study, we highlighted a weakness in the current evaluation models in place for controlling fishing in Brazil. In large part, this limitation results from management practices that fail to provide a reasonable record of catches with species-specific data, in turn confounding attempts to prevent illegal fishing and trade of endangered species. De Franco et al. (2012) also noted this same failure with respect to Brazilian guitarfish exploitation.

Worldwide, fish products are processed for commercialization in different ways, thus hindering visual inspection of morphological characters essential for taxonomic identification of captured species (Bornatowski et al., 2013). In Brazil, molecular techniques have been used to identify species of the genus Squatina (Falcão et al., 2014) and guitarfish (De Franco et al., 2012). In addition, studies have used molecular markers to identify several species of Elasmobranchs (Mendonça et al., 2010; Ribeiro et al., 2012; Domingues et al., 2013), as well as identify fraudulent labeling of different species of fish (Carvalho et al., 2015) and species threatened with extinction (Rodrigues et al., 2016).

In Brazilian markets, Elasmobranchs are usually sold as "cação", one of their popular trade names. This generalized and nonspecific labeling also complicates efforts to curb consumption of endangered species (Bornatowski et al., 2013). The mitigation of this practice could be done through the use of modern techniques of genetic identification, in particular DNA barcoding to identify Elasmobranchs at species level. This would result in correct identification before sales in supermarkets (Bornatowski et al., 2013).

It is crucial for Brazil to resume its data collection system for all of its fisheries, including data on landings, in order to ensure efficient policymaking and effective management and conservation. To ensure sustainable fishing and inhibit crimes of exploitation, we need to (i) formulate species-level statistics using modern molecular tools, (ii) maintain and continually update lists of endangered species, and (iii) improve the implementation of long-term conservation and management programs.

In conclusion, crimes against the environment, including such practices as the capture and trade of protected species and fraudulent labeling, need to be directly tackled, along with increasing public awareness. This can be directly achieved through the use of techniques like DNA barcoding, which has proven to be a powerful tool in the monitoring and conservation of traded and natural resources. As such, it should be proposed as a standard procedure for identification of species in Brazilian fish landings and in the surveillance of commercial fraud along the production chain through the final delivery of fish products to consumers.

\section{Acknowledgements}

The authors would like to thank all those who collaborated in the development of this study, especially to the field researchers, who obtained the genetic samples.

\section{Funding}

The authors thank all those who contributed to this study, including the Conselho Nacional de Desenvolvimento Científico e Tecnológico (CNPq). This work was supported by the Fundação de Amparo à Pesquisa do Estado de São Paulo - BIOTA/FAPESP (grant numbers 2011, 23787-0), and Bunholi IV was supported by the Programa de Bolsas de Iniciação Científica (PIBIC/PIBIC-Af 2016-2017).

\section{References}

Benson, D.A., Cavanaugh, M., Clark, K., Karsch-Mizrachi, I., Lipman, D.J., Ostell, J., Sayers, E.W., 2017. GenBank. Nucleic Acids Res. 45, D37. http://dx.doi.org/10. 1093/nar/gkx1094. (Database issue).

Bornatowski, H., Braga, R.R., Vitule, J.R.S., 2013. Shark mislabeling threatens biodiversity. Science 340 (6135), 923. http://dx.doi.org/10.1126/science.340.6135. 923-a.

Borsa, P., 2016. Comments on "Annotated checklist of the living sharks, batoids and chimaeras (Chondrichthyes) of the world, with a focus on biogeographical diversity" (Weigmann,). J. Fish Biol. http://dx.doi.org/10.1111/jfb.13235.

Camhi, M., 1998. Sharks and Their Relatives: Ecology and Conservation (No. 20). IUCN.

Carvalho, D.C., Palhares, R.M., Drummond, M.G., Frigo, T.B., 2015. DNA barcoding identification of commercialized seafood in South Brazil: a governmental regulatory forensic program. Food Control 50, 784-788. http://dx.doi.org/10.1016/j.foodcont. 2014.10.025.

Castro, J.I., 1987. The Position of Sharks in Marine Biological Communities: an Overview. Sharks, an Inquiry into Biology, Behavior, Fisheries, and Use. Oregon State University Extension Service, Corvallis, pp. 11-17.

Castro-Aguirre, J.L., Espinosa Pérez, H., Huidobro Campos, L., 2006. Dos nuevas especies del género Squatina (Chondrichthyes: Squatinidae) del Golfo de México. Rev. Biol. Trop. 54 (3), 1031-1040.

Chiaramonte, G., Vooren, C.M., 2007. Squatina guggenheim. The IUCN Red List of Threatened Species 2007: e.T39330A10202558. Downloaded on 16 May 2017. 
http://www.iucnredlist.org).

Clarke, S.C., McAllister, M.K., Milner-Gulland, E.J., Kirkwood, G.P., Michielsens, C.G., Agnew, D.J., Pikitch, E.K., Nakano, H., Shivji, M.S., 2006. Global estimates of shark catches using trade records from commercial markets. Ecol. Lett. 9 (10), 1115-1126. http://dx.doi.org/10.1111/j.1461-0248.2006.00968.x.

Compagno, L.G.V., 2005. Checklist of living chondrichthyes. In: Hamlett, W.C. (Ed.), Reproductive Biology and Phylogeny of Chondrichthyes: Sharks, Batoids, and Chimaeras. Science Publishers, Inc., Enfield, New Hampshire, pp. 501-548.

Cousseau, M.B., Figueroa, D.E., 2001. Las especies del género Squatina en aguas de Argentina (Pisces: Elasmobranchii: Squatinidae). Neotrópica 47, 85-86.

Davidson, L.N., Krawchuk, M.A., Dulvy, N.K., 2016. Why have global shark and ray landings declined: improved management or overfishing? Fish Fish. (Oxf.) 17 (2), 438-458. http://dx.doi.org/10.1111/faf.12119.

De Franco, B., Fernandes Mendonça, F., Oliveira, C., Foresti, F., 2012. Illegal trade of the guitarfish Rhinobatos horkelii on the coasts of central and southern Brazil: genetic identification to aid conservation. Aquat. Conserv. 22 (2), 272-276. http://dx.doi. org/10.1002/aqc.2229.

Domingues, R.R., Amorim, A.F., Hilsdorf, A.W.S., 2013. Genetic identification of Carcharhinus sharks from the southwest Atlantic Ocean (Chondrichthyes: Carcharhiniformes). J. Appl. Ichthyol. 29 (4), 738-742. http://dx.doi.org/10.1111/ jai.12154.

Dulvy, N.K., Baum, J.K., Clarke, S., Compagno, L.J., Cortés, E., Domingo, A., Fordham, S., Fowler, S., Francis, M.P., Gibson, C., Martínez, J., 2008. You can swim but you can't hide: the global status and conservation of oceanic pelagic sharks and rays. Aquat. Conserv 18 (5), 459-482. http://dx.doi.org/10.1002/aqc.975.

Dulvy, N.K., Fowler, S.L., Musick, J.A., Cavanagh, R.D., Kyne, P.M., Harrison, L.R. Carlson, J.K., Davidson, L.N., Fordham, S.V., Francis, M.P., Pollock, C.M., 2014 Extinction risk and conservation of the world's sharks and rays. Elife 3, e00590. http://dx.doi.org/10.7554/eLife.00590.

Edgar, R.C., 2004. MUSCLE: multiple sequence alignment with high accuracy and high throughput. Nucleic Acids Res. 32 (5), 1792-1797. http://dx.doi.org/10.1093/nar/ gkh340.

Falcão, L.H.O., Furtado-Neto, M.A.A., Maggioni, R., Faria, V.V., 2014. Prospective molecular markers for the identification of illegally traded angelsharks (Squatina) and dolphin (Sotalia guianensis). Genet. Mol. Res. 13, 9710-9717. http://dx.doi.org/10. 4238/2014.November.24.2.

Felsenstein, J., 1985. Confidence limits on phylogenies: an approach using the bootstrap. Evolution 39 (4), 783-791. http://dx.doi.org/10.1111/j.1558-5646.1985.tb00420.x.

Field, I.C., Meekan, M.G., Buckworth, R.C., Bradshaw, C.J., 2009. Susceptibility of sharks, rays and chimaeras to global extinction. Adv. Mar. Biol. 56, 275-363. http://dx.doi. org /10.1016/S0065-2881(09)56004-X.

Furtado-Neto, M., Carr, S., 2002. Molecular Genetics of Some Brazilian Sharks. The IUCN/ SSC Shark Specialist Group, Shark News. http://ufdcimages.uflib.ufl.edu/UF/00/09/ 04/96/00014/Binder14.pdf.

Helyar, S.J., Lloyd, H.A.D., de Bruyn, M., Leake, J., Bennett, N., Carvalho, G.R., 2014. Fish product mislabelling: failings of traceability in the production chain and implications for illegal, unreported and unregulated (IUU) fishing. PLoS One 9 (6), e98691. http://dx.doi.org/10.1371/journal.pone.0098691.

IUCN, 2017. The IUCN Red List of Threatened Species. Version 2017-1: Table 4a. Downloaded on 12 May 2017. http://www.iucnredlist.org).

Kimura, M., 1980. A simple method for estimating evolutionary rates of base substitutions through comparative studies of nucleotide sequences. J. Mol. Evol. 16 (2), 111-120. http://dx.doi.org/10.1007/BF01731581.

Kumar, S., Stecher, G., Tamura, K., 2016. MEGA7: molecular evolutionary genetics analysis version 7.0 for bigger datasets. Mol. Biol. Evol. 33 (7), 1870-1874. http:// dx.doi.org/10.1093/molbev/msw054.

Last, P.R., White, W.T., 2008. Three new angel sharks (Chondrichthyes: Squatinidae) from the Indo-Australian region. Zootaxa 1734, 1-26.

Last, P.R., Seret, B., Naylor, G.J., 2016. A new species of guitarfish, Rhinobatos borneensis sp. nov. with a redefinition of the family-level classification in the order Rhinopristiformes (Chondrichthyes: Batoidea). Zootaxa 4117 (4), 451.

Lessa, R., Vooren, C.M., 2016. Pseudobatos horkelii. The IUCN Red List of Threatened Species 2016: e.T41064A103933918. Downloaded on 15 May 2017. http://www. iucnredlist.org.

Liu, S.Y.V., Chan, C.L.C., Lin, O., Hu, C.S., Chen, C.A., 2013. DNA barcoding of shark meats identify species composition and CITES-listed species from the markets in Taiwan. PLoS One 8 (11), e79373. http://dx.doi.org/10.1371/journal.pone. 0079373.

Maduna, S.N., Rossouw, C., Silva, C., Soekoe, M., Bester-van der Merwe, A.E., 2017. Species identification and comparative population genetics of four coastal houndsharks based on novel NGS-mined microsatellites. Ecol. Evol. 7 (5), 1462-1486. http://dx.doi.org/10.1002/ece3.2770.

Maralit, B.A., Aguila, R.D., Ventolero, M.F.H., Perez, S.K.L., Willette, D.A., Santos, M.D., 2013. Detection of mislabeled commercial fishery by-products in the Philippines using DNA barcodes and its implications to food traceability and safety. Food Control 33 (1), 119-125. http://dx.doi.org/10.1016/j.foodcont.2013.02.018.

Mendonça, F.F., Hashimoto, D.T., De-Franco, B., Porto-Foresti, F., Gadig, O.B.F., Oliveira, C., Foresti, F., 2010. Genetic identification of lamniform and carcharhiniform sharks using multiplex-PCR. Conserv. Genet. Resour. 2 (1), 31-35. http://dx.doi.org/10. 1007/s12686-009-9131-7.

Meyers, E.K., Tuya, F., Barker, J., Jiménez Alvarado, D., Castro-Hernández, J.J., Haroun, R., Rödder, D., 2017. Population structure, distribution and habitat use of the Critically Endangered Angelshark, Squatina Squatina, in the Canary Islands. Aquat. Conserv. http://dx.doi.org/10.1002/aqc.2769.

Migone, A., Howlett, M., 2012. From paper trails to DNA barcodes: enhancing traceability in forest and fishery certification. Nat. Resour. J. 421-441. http://www.jstor.org/ stable/24889673.

Molina, J.M., Cooke, S.J., 2012. Trends in shark bycatch research: current status and research needs. Rev. Fish Biol. Fish. 22 (3), 719-737. http://dx.doi.org/10.1007/ s11160-012-9269-3.

Musick, J.A., Kyne, P.M., 2007. Squatina punctata. The IUCN Red List of Threatened Species. http://dx.doi.org/10.2305/IUCN.UK.2007.RLTS.T63150A23737.en.

Ogden, R., 2008. Fisheries forensics: the use of DNA tools for improving compliance, traceability and enforcement in the fishing industry. Fish Fish. (Oxf.) 9 (4), 462-472. http://dx.doi.org/10.1111/j.1467-2979.2008.00305.x.

Oliver, S., Braccini, M., Newman, S.J., Harvey, E.S., 2015. Global patterns in the bycatch of sharks and rays. Mar. Policy 54, 86-97. http://dx.doi.org/10.1016/j.marpol.2014. 12.017 .

Ratnasingham, S., Hebert, P.D., 2007. BOLD: the barcode of life data system. Mol. Ecol. Notes 7 (3), 355-364. http://dx.doi.org/10.1111/j.14718286.2007.01678.x. http:// www.barcodinglife.org.

Ribeiro, A.D.O., Caires, R.A., Mariguela, T.C., Pereira, L.H.G., Hanner, R., Oliveira, C., 2012. DNA barcodes identify marine fishes of Sao Paulo State, Brazil. Mol. Ecol. Resour. 12 (6), 1012-1020. http://dx.doi.org/10.1111/1755-0998.12007.

Rodrigues, A.D.S., Brandão, J.H.S.G., Bitencourt, J.D.A., Jucá-Chagas, R., Sampaio, I., Schneider, H., Affonso, P.R.A.D.M., 2016. Molecular identification and traceability of illegal trading in Lignobrycon myersi (Teleostei: Characiformes), a threatened Brazilian Fish species, using DNA barcode. Sci. World J. 2016. http://dx.doi.org/10. 1155/2016/9382613.

Saitou, N., Nei, M., 1987. The neighbor-joining method: a new method for reconstructing phylogenetic trees. Mol. Biol. Evol. 4 (4), 406-425. http://dx.doi.org/10.1093/ oxfordjournals.molbev.a040454.

Sebastian, H., Haye, P.A., Shivji, M.S., 2008. Characterization of the pelagic shark-fin trade in north-central Chile by genetic identification and trader surveys. J. Fish Biol. 73 (10), 2293-2304. http://dx.doi.org/10.1111/j.1095-8649.2008.02016.x.

Silva, K.D., 1996. Estudo comparativo dos parâmetros populacionais da reprodução dos cação-anjo Squatina argentina Marini, 1930, Squatina guggenheim (Marini, 1936) e Squatina occulta Vooren \& Silva, 1991, no sul do Brasil. Departamento de Oceanografia da Fundação Universidade de Rio Grande, Rio Grande.

Solé-Cava, A.M., Levy, J.A., 1987. Biochemical evidence for a third species of angel shark off the east coast of South America. Biochem. Syst. Ecol. 15 (1), 139-144. http://dx. doi.org/10.1016/0305-1978(87)90093-7.

Solé-Cava, A.M., Vooren, C.M., Levy, J.A., 1983. Isozymic differentiation of two sibling species of Squatina (chondrichthyes) in South Brazil. Comp. Biochem. Physiol. B: Biochem. Mol. Biol. 75 (2), 355-358. http://dx.doi.org/10.1016/0305-0491(83) 90339-5.

Soto, J.M.R., 2001. Annotated systematic checklist and bibliography of the coastal and oceanic fauna of Brazil. Mare Magnum 1 (1), 51-120 51, 120.

Stelbrink, B., von Rintelen, T., Cliff, G., Kriwet, J., 2010. Molecular systematics and global phylogeography of angel sharks (genus Squatina). Mol. Phylogenet. Evol. 54 (2), 395-404. http://dx.doi.org/10.1016/j.ympev.2009.07.029.

Stevens, J.D., Bonfil, R., Dulvy, N.K., Walker, P.A., 2000. The effects of fishing on sharks, rays, and chimaeras (chondrichthyans), and the implications for marine ecosystems. ICES J. Mar. Sci. 57 (3), 476-494. http://dx.doi.org/10.1006/jmsc.2000.0724.

Vannuccini, S., 1999. Shark Utilization, Marketing and Trade (No. 389). Food Agriculture Org.

Vaz, D.F., De Carvalho, M.R., 2013. Morphological and taxonomic revision of species of Squatina from the Southwestern Atlantic Ocean (Chondrichthyes: Squatiniformes: Squatinidae). Zootaxa 3695 (1), 1-81.

Villwock de Miranda, L., Vooren, C.M., 2003. Catch and effort of demersal elasmobranchs in south Brazil from 1975 to 1997. Frente Marítimo 19, 217-231.

Vooren, C.M., da Silva, K.G., 1992. On the taxonomy of the angel sharks from Southern Brazil, with the description of Squatina occulta sp. n. Revista Brasileira de Biologia 51 (3), 589-602.

Vooren, C.M., Klippel, S. (Eds.), 2005. Ações para a conservação de tubarões e raias no sul do Brasil. Sandro Klippel.

Walker, T.I., 1999. Can shark resources be harvested sustainably? A question revisited with a review of shark fisheries. Mar. Freshw. Res. 49 (7), 553-572. http://dx.doi. org/10.1071/MF98017.

Ward, R.D., Zemlak, T.S., Innes, B.H., Last, P.R., Hebert, P.D., 2005. DNA barcoding Australia's fish species. Philos. Trans. R. Soc. B 360 (1462), 1847-1857. http://dx doi.org/10.1098/rstb.2005.1716.

Weigmann, S., 2016. Annotated checklist of the living sharks, batoids and chimaeras (Chondrichthyes) of the world, with a focus on biogeographical diversity. J. Fish Biol. 88 (3), 837-1037. http://dx.doi.org/10.1111/jfb.12874. 